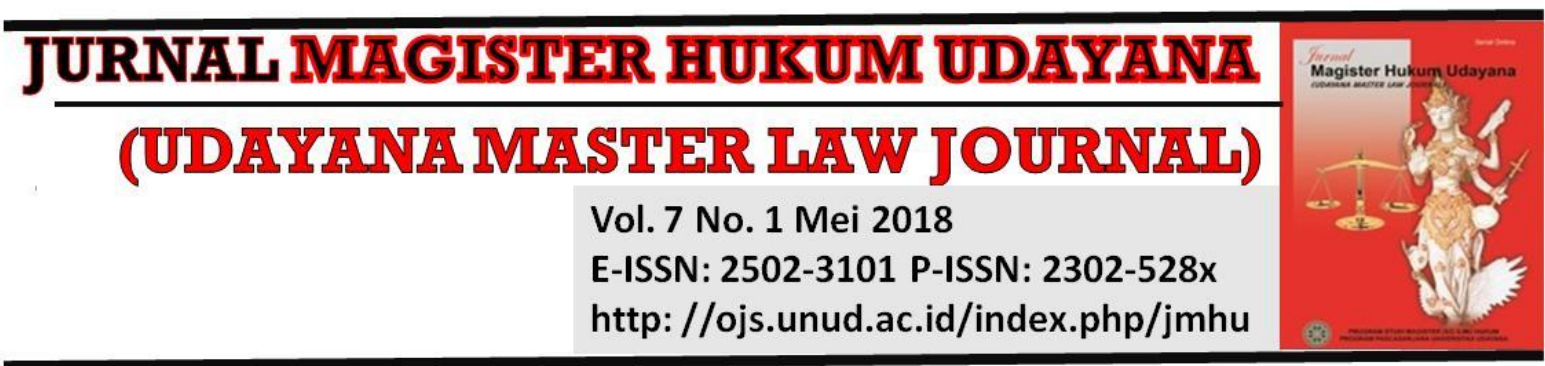

\title{
Criminal Sanction for Users of Pornographic Content on Internet Sites: A Pornographic Law Perspecive
}

\author{
Ferry IrawanFebriansyah ${ }^{1}$ \\ ${ }^{1}$ Fakultas Hukum, Universitas Muhammadiyah Ponorogo, \\ E-mail: ferryirawanfebriansyah@gmail.com
}

\begin{tabular}{l}
\hline Info Artikel \\
\hline Masuk : 6 Pebruari 2018 \\
Diterima : 21 Mei 2018 \\
Terbit : 28 Mei 2018 \\
Keywords : \\
Cyberporn, Internet, Juridical, \\
Criminal Sanction \\
Corresponding Author: \\
Ferry IrawanFebriansyah, E- \\
mail: \\
ferryirawanfebriansyah@gm \\
ail.com \\
DOI : \\
10.24843/JMHU.2018.v07.i01. \\
p01
\end{tabular}

Abstract
Inside the internet, information becomes something very
important and really life. Mobility is so fast and can be
downloaded, produced, and then uploaded again. The internet
network is one of the most popular information sources today.
Many internet users access pornographic websites because these
pornographic websites supported by the development of rapid
internet. The purpose of this study is to review Pornographic
Law related to cyberporn. This criminal act is called Cyberporn.
Given the enormous impact that is caused by the act of
pornography, especially on the internet site, the government
legalized the bill against pornography into pornography law with
clear criminal provisions. This research method using normative
law research method, with a normative juridical approach related
to pornography. In relation to this type of research is a normative
legal research, then the source of legal material used is the
legislation. In accordance with this type of research, the analysis
used is a normative juridical analysis that relies on the ability of
legal argumentation, legal interpretation, and legal reasoning
related to criminal provisions in pornography law. From the
results of research have found that criminal provisions in the law
number 44 of 2008 on pornography is quite clear that everyone
who access on porn sites on the internet threatened with criminal
sanctions. Juridically, criminal provisions in pornography law
provide legal certainty is quite clear.

\section{Introduction}

In principle, laws are rules that are used to achieve social life in order to be safe, peaceful, and prosperous. Due to the increasing influences of social life, the law follows the social changes that have grown in society. The occurrence of legal change can be through two forms, the society changes first, the new law comes to legalize the change, here the changes that occur are passive, the law always comes after the change occurs. While other forms are the law as a means to change society to a better (law as tool of social engineering). In this form, the change of law must be tended change and must be planned (planned change) in such a way as expected. The change of this model is active, meaning that the authorities are actively planning and directing the legal reform concept to work effectively. ${ }^{1}$

\footnotetext{
${ }^{1}$ Manan, A.(2005).Aspek-AspekPengubahHukum. Jakarta. Prenada Media.p. 10-11.
} 
Substantially in the science of law is studied about the rule of law in both broad and narrow terms. The law's method in the broad sense is usually interpreted as a rule, both written and oral, governing how we as a society do or do not do. Legal judgments in the broad sense include legal principles, legal rules in the strict sense or value of norms, and concrete legal rules. Legal principles are basic and abstract basic thoughts, the background of concrete law rules contained within and behind every legal system incarnate in legislation and judgment. Meanwhile, the rule of law in the strict sense or the value of the norm is the formulation of an objective view of judgments or attitudes that should be done or not done, which is prohibited or recommended to be executed is a more concrete value of the principle of law.

In the virtual world of the internet, information becomes something very important and really life. Mobility is so fast and can be downloaded, produced, and then uploaded again. It can be done by anyone, anytime and anywhere. The Internet is a familiar word for those of us who are already familiar with technology. The internet network is one of the most popular information sources today. Through the relatively cheap and affordable cost, we are able to get information in various forms ranging from the form of text in the form of writing, images, graphics, to sound or voice media with reach across the world with free and unlimited.

According to Brenner, in the earliest development on internet use in can be revealed that Internet use, besides its enormous advantages, also carries the possibility of abuse and the potential danger that addiction could develop. ${ }^{2}$ In addition, the Internet can also be a place for children encounter risks such as unwanted sexual solicitation, bullying and harassment or even inappropriate marketing and advertising. ${ }^{3}$

Aspects of infinity that is a means to access pornographic sites for Internet users who want to find satisfaction. In addition to the advantages of this information media, we are also faced with the biggest problems that threaten the nation's morality is the spread of pornographic websites that can be accessed so freely by the internet users.

Today, the internet has shaped the society with a new culture. Communities no longer blocked by territorial boundaries between formerly established countries are very rigid. A new society with the most perfect freedom of activity and creativity. But behind the glamor, the internet also gave birth to new unrest. Among them came a more sophisticated crime in the form of "Cybercrime". This is marked by the rapid growth of porn sites in various sites that are very tempting display or where the spread of false news (libel) the most effective. In fact, recent data shows that the greatest trade transactions via the Internet are derived from this pornography business. ${ }^{4}$ Topo Santoso states that the term pornography comes from the word "pornographic" which

\footnotetext{
2 Demetrovics, Z., Szeredi, B., \&Rózsa, S. (2008). The three-factor model of Internet addiction: The development of the Problematic Internet Use Questionnaire. Behavior Research Methods, 40(2), p. 564.

${ }^{3}$ Byrne, J., \& Burton, P. (2017). Children as Internet users: how can evidence better inform policy debate?. Journal of Cyber Policy. 2(1). p. 40.

${ }^{4}$ Makarim, E.(2004).KompilasiHukumTelematika. Jakarta. Raja GrafindoPersada. p. 196-197.
} 
comes from the Greek "pornographos". Pornography is also called "obscene"which gives rise to lust or passion. ${ }^{5}$

People are talking about pornography and all its problems. Countless discussions, workshops that discuss this one issue. Starting from a review conducted by academics, journalistic practitioners to studies made by scholars and community leaders. The debate of pros and cons arose almost every discourse on pornography. Pornography itself has many substances that have different definitions between one country and another. Many countries legalize pornography and many also prohibit, however, this type of child pornography is always agreed as a ban in all countries. Referring to some conventions one of them is:

Article 9-Offences related to child pornography

1. Each Party shall adopt such legislative and other measures as may be necessary to establish as criminal offences under its domestic law, when committed intentionally and without right, the following conduct:

a. producing child pornography for the purpose of its distribution through a computer system;

b. offering or making available child pornography through a computer system;

c. distributing or transmitting child pornography through a computer system;

d. procuring child pornography through a computer system for oneself or for another person;

e. possessing child pornography in a computer system or on a computer-data storage medium.

2. For the purpose of paragraph 1 above, the term "child pornography" shall include pornographic material that visually depicts:

a. a minor engaged in sexually explicit conduct;

b. a person appearing to be a minor engaged in sexually explicit conduct;

realistic images representing a minor engaged in sexually explicit conduct.

3. For the purpose of paragraph 2 above, the term "minor" shall include all personsunder 18 years of age. A Party may, however, require a lower age-limit, which shall be not less than 16 years.

4. Each Party may reserve the right not to apply, in whole or in part, paragraphs 1, sub-paragraphs $\mathrm{d}$. and e, and 2, sub-paragraphs b. and c. ${ }^{6}$

This we associate with anti-pornography laws concerning crime on the internet site.

Many internet users access pornographic websites because these pornographic websites support the development of the internet. This criminal act is called Cyberporn. Cyberporn is a crime of pornography on the internet site. The position of Cyberporn is very supportive in the development of Internet technology, without these pornographic sites it will not advance an information technology that is called the internet.

Judged by the positive law as stipulated in Article 1 of Law Number 44 of 2008 on pornography, it is mentioned that, Pornography is a picture, sketch, photo illustration, writing, sound, sound, motion picture, animation, cartoon, conversation, gestures, or

${ }^{5}$ Bunga, D. (2011). Penanggulangan Pornografi dalam Mewujudkan Manusia Pancasila. Jurnal Konstitusi. 8(4). p. 456.

${ }^{6}$ ETS 185-Convention on Cybercrime. Budapest. 23.XI.200, p. 6-7. 
form other messages through various forms of communication media and / or public performances, containing obscenity or sexual exploitation in violation of moral norms in society. ${ }^{7}$ In addition to such dimensions then Pornography can also be interpreted as lewd writings are immoral and dirty. ${ }^{8}$ Further, this study analyzes the criminal provisions of pornography on the internet site in terms of law Number 44 of 2008 on Pornography and the active role of this law in ensnaring Cyberporn crime on the internet site.

\section{Research Methods}

This study uses normative legal research methods. Normative legal research is a legal research that puts the law as the norm system. The norm system is about principles, norms, rules of legislation, court decisions, covenants and doctrines or teachings. The object of normative law research always takes the issue of law as the system of norms or rules used to present prescriptive justification of the provisions of a legal event. The norm system in the simplest sense is the rule or rule system. ${ }^{9}$

Soekanto said that the method of normative law research or literature law research method is a method or method used in legal research conducted by examining existing library materials..$^{10}$ Normative legal research is basing the idea of the rule of law as the main legal material of research is legal materials such as laws and regulations, court decisions until the local regulations then used with the emphasis of legal interpretation and legal construction to obtain legal rules, conception the legal concepts, the inventory of the rule of law and the application of the law by reviewing existing issues and reviewing and reviewing the role of law number 44 of 2008 on pornography and then linked to the crime of pornographic content users on the internet site.

\subsection{Source of Legal Material}

In relation to this type of research is a normative legal research, the source of legal material used consists of primary legal materials and secondary legal materials. Primary legal material consists of legislation, while secondary legal materials consist of books, articles, journals, internet, magazines, legal documents and legal dictionaries relating to research problems.

\subsection{Technique of Collection and Processing of Legal Material}

The collection of legal materials is done by inventory legislation, and library materials as secondary legal materials and other legal materials such as internet, journals, magazines and so forth. The legal materials are identified, collected, separated according to the nature of the legal substance, then the legal materials are selected according to the needs of the analysis of existing social problems.

\subsection{Material Legal Analysis}

In accordance with this type of research, the analysis used is a normative juridical analysis that relies on the ability of legal argumentation, legal interpretation, and legal

\footnotetext{
${ }^{7}$ Law Number 44 Year 2008 About Pornography.

${ }^{8}$ Qohar, M. K. A.KamusIstilahPengetahuanPopuler, BintangPelajar, p. 196.

${ }^{9}$ Ranuhandoko. (2003).TerminologiHukum. Jakarta. Grafik. p. 419.

10 Soekanto, S. \&Mamudji, S. (2009).PenelitianHukumNormatifSuatuTinjauanSingkat. Cetakan ke-

11 Jakarta. PT Raja GrafindoPersada. p. 13-14.
} 
reasoning related to the laws studied. This analysis is expected to provide clarity to the problems raised in the study.

\section{Result and Discussion}

\subsection{The Relevance of Pornography as a Form of Criminal Acts}

The main purpose of a computer system is to process the data obtained in order to produce an information. At least the work of computers is hung on three factors including human factors (brainware), hardware, and software. ${ }^{11}$ These three factors are interdependent. If one of these factors does not work, then there will be no action that is the operation of the computer. Then if these three factors we associate with the illegal use of computers will occur violations that occurred. An example of a pornography crime on the internet. Relevance in this case is interpreted as still the need for pornography serve as a crime. An act is defined as an act of criminal penalty called criminalization. There are several criteria for an act to be criminalized, among others: 12

1. The use of criminal law should pay attention to the national development objective of realizing a just and prosperous society which is equally material and spiritually based on Pancasila.

2. The act which is attempted to be prevented or overcome by criminal law shall be undesirable act that is harmful (material and or spiritual) for the citizen.

3. The use of criminal law should also take into account the principles of cost and yield.

4. The use of criminal law must also consider the capacity or ability of the workforce of a legal entity that is not to have the ability to load the task.

In criminalizing the act of pornography there is a fundamental problem. Fundamental issues relate to the criteria in determining an act as a criminal act. This issue is not easy, given that pornography is sometimes regarded as a mild and private crime. Therefore, it is considered a Victimless Crime because the victim wants the crime itself. However, if examined in depth related to the loss and the victims who fell due to this pornography looks amazing. Given this crime can undermine the morality of a nation. The significance of this nation's morality is related to the continuity of development, especially the younger generation of the nation.

The younger generation of Indonesia should not be polluted by pornographic pollution which may create access to other criminal morals such as rape, fornication, trafficking in women, trafficking in children, deviant sexual behavior and so on. Besides, pornography is prohibited by religious norms and morality norms in society, therefore the act is seen as a disgraceful and immoral act. Pornography can be linked as a form of crime which contains clear sanctions and is regulated in law.

\subsection{The Role of the Pornography Act}

One fact is that this electronic information and transaction law and pornography law has been transformed into an information filter in violation of morals. Yet what is contained in the laws of information and electronic transactions is much broader than

\footnotetext{
${ }^{11}$ Hamzah, A., \&Marsita, B. D. (1987).Aspek-AspekPidana di BidangKomputer. Jakarta. Sinar Grafika.p. 392.

${ }^{12}$ Sudarto, (1986).Hukum dan Hukum Pidana. Bandung.Alumni. p. 44.
} 
pornography itself. Ranging from permitted acts to prohibited acts such as consumer guarantees, legal proof before the law, use of domain names, electronic system administration up to criminal provisions such as disseminating information violating ethics, containing racism, infiltration and vandalism against an electronic system .

Such acts need to be straightened out as activities by utilizing communication and information technology require a basic of law. This pornography law should be perfected, of course we all agree. As a process this law has provided the basis for activities utilizing electronic technology. The emergence of the idea of filtering blindly seems unlikely to be effective. One fact is that information on the internet is not limited to material that violates ethics, so the government's effort to make this law as a tool to prevent such information is unlikely to succeed as opposed to the technology itself which at any time develops.

Until now, although prohibited, the information that is considered to violate the morals remains accessible to the public. Efforts to filter through repressive means and strategies will not have a positive impact on our nation's generation. Much more effective through persuasive ways and strategies by educating the public through informal or formal forums, or through other educational channels such as the creation of an internet guide book.

The prohibition and limitation of pornographic laws, especially articles 4 and 5, which read, (1) Everyone is prohibited from producing, producing, reproducing, exporting, offering, selling, importing, exporting, offering, trading, leasing or otherwise providing explicit pornography load:
a. sexual, including distorted sexuality;
b. sexual violence;
c. masturbation;
d. nudity or impressive display of nudity;
e. genitals; or
f. child pornography.

In paragraph (2), Everyone is prohibited from providing pornographic services which:

a. presents explicitly nudity or an impressive display of nudity;

b. explicitly presenting genitalia;

c. exploit or show off sexual activity; or

d. offer or advertise, directly or indirectly, sexual services.

In Article 5 it reads, everyone is prohibited from lending or downloading pornography as referred to in Article 4 paragraph (1). The restrictions and limitations set forth in these articles will be ineffective when applied to a site on the internet site due to the nature of the internet that is too universal so that this law is difficult to reach the perpetrators of criminal acts on the internet site. In addition to this law there needs to be cooperation between countries around the world against the prohibition of pornography on the internet site.

In addition to the laws of Pornography, the Criminal Code (KUHP)and electronic transaction laws are also regulated on pornography. In the Criminal Code in Chapter 
XIV Crimes Against Decency in Article 281 Threatened with imprisonment of two years and eight months or a fine of four thousand five hundred rupiahs: paragraph 1 "whoever intentionally in public violates decency". In the ITE (Information and electronic transactions)Law Article 27 paragraph (1) regulates the prohibition of distributing, transmitting, and / or making accessible Electronic Information or Documents which have a content that violates decency.

The question arises as to whether other countries can accept this cooperation while the internet business is advanced due to the role of porn sites. We need to know that advances in information technology such as advanced internet due to porn sites. When porn sites are banned by all countries in the world, then internet technology will not be able to advance. Therefore, some countries in the world legalize porn sites to support the advancement of information technology is the Internet and automatically will not want when doing cooperation associated with blocking porn sites on the internet.

Pornography law plays an active role in criminal prosecution on internet sites although there are still many obstacles in its application in society. Let us look back at the time when the bill pornography was formed, many pros and cons are accompanying until this law is signed and signed by the president. Nevertheless we must embrace a legal fiction that is a draft law when it has been passed into law should be adhered to by all Indonesian citizens.

The articles relevant to the crime of pornography on the Internet website, among others, are Article 1 which reads, in this law is meant byc:

1. Pornography is a drawing, sketch, illustration, photo, writing, sound, sound, motion picture, animation, cartoon, conversation, gesture, or other form of message through various forms of communication media and / or public performances that contain obscenity or sexual exploitation that violates the norms of morality in society.

2. Pornography services are any kind of pornographic services provided by individuals or corporations through live performances, cable television, terrestrial television, radio, telephone, internet, and other electronic communications as well as newspapers, magazines and other printed materials.

In chapter 18 it has been asserted that the role of the government as a deterrent to pornography. Article 18 reads, the Government and the Regional Government shall undertake the prevention of the manufacture, dissemination and use of pornography. While Article 19 reads, to perform the prevention as referred to in Article 18, the Regional Government is authorized:

1. to terminate the network of the manufacture and dissemination of pornographic products or services of pornography, including the blocking of pornography by internet in its territory;

2. supervise the manufacture, dissemination and use of pornography in its territory;

3. undertake co-operation and coordination with various parties in preventing the manufacture, dissemination and use of pornography in its territory; and

4. develop communication, information, and education systems in order to prevent pornography in its territory. 
The above articles are articles of the pornography law that are closely related to pornographic crime on the internet site. All restrictions on these offenses are set out in the foregoing articles.

\subsection{The Role of Pornography and Legal Acts}

It has been mentioned earlier that the law has provisions that apply juridical, sociological and philosophical provisions. The law has a compelling nature that when the law has been invited, all must obey it without exception. In this discussion we linked with the law number 44 of 2008 on pornography. Pornography in this case is pornography in cyberspace or internet. Pornography on the internet includes a crime because the law number 44 of 2008 on pornography has regulated it. This pornography law acts as a legal rule relevant to pornography and is a filter for the public to understand the negative effects of pornography, but in this discussion the author only examines about pornography related to the internet. The substance of this pornography law is clear enough, but the sophistication of internet technology is difficult to reach by this law because of different jurisdictions. In addition, the articles contained in it are also getting left behind by internet technology because the internet has the nature of updates every time while the law in amendment or revision it takes no time.

The role of this pornography law is as a filter of a criminal act of pornography, especially internet pornography in order to occur restrictions for users of internet sites in order not to do things that smell porn on a cyberspace site that is the internet. With the new law is expected for people to know the benefits of losses to access porn and legal action against perpetrators of pornography on the internet. In addition, it can prevent a pornographic act that affect the moral decline of the generation of the Indonesian nation.

From the results of research have found data internet users who access porn sites. Ironically all internet users have access to porn sites from a mere fun to other needs. From the research can be concluded that all internet users ever violate the law on pornography. There are some who do not understand about the rule of law about pornography law and some do not know the rule of law so that they feel safe and legitimate in doing pornographic crime (Cyberporn).

Legal action has been done by the authorities, such as sweeping to the cafes and blocking a porn site, but the difficulty of handling in this internet pornography that makes many problems in handling. As to the extent of this law on pornography, the effectiveness of this law is questionable because of the many obstacles in handling pornography on this website. Actually with reference to article 282 and article 283 of the Criminal Code is sufficient in ensnaring the problem of pornography. ${ }^{13}$

Criminal acts classified in criminal offenses are formulated from Article 281 to Article 303 of the Indonesian Criminal Code, while criminal offenses classified as ethnic violations are formulated in Articles 532 up to Article 547 of the Criminal Code.

${ }^{13}$ Raharjo, A. (2007). Kajian YuridisTerhadap Cyberporn Dan UpayaPencegahan Serta PenanggulanganPenyebarannyadi Internet. JurnalHukumRespublica.p. 38. See, Hamzah, A. (2009).Delik-DelikTertentu (SpecialeDelicten) di dalam KUHP. Jakarta, SinarGrafika. p. 154. 
Basically in terms of the content of both groups of moral decency, we note that the criminal act of morality in the Criminal Code is largely confined to mere mere sexual contexts, although the defining of this decency can not be found in the same perception. ${ }^{14}$

With the existence of pornography law it is increasingly difficult to handle from the authorities in terms of interpretation of the articles in this law because it is so broad definition of internet pornography. There are also other laws, namely law number 11 of 2008 on information and electronic transactions that regulate pornography on the internet site. This is what makes the law overlap in its application in the life of nation and state. The difference of substance of this law is problematic so that if there is a case of pornography on the internet then the police will experience obstacles in ensnare Cyberporn actors because the articles in this law is too broad in interpreting it. So far there has been no case related to pornography on the internet that entangled the articles in pornography law.

Internet technology is an advanced technology that has not been widely accepted by the people of Indonesia. Need more learning about this internet technology so that there is no mistake the use of internet technology in violation of law. Then in relation to the crime of pornography, internet users often do these things regardless of whether their actions violate the law or not. With the sophistication of internet technology and the lack of socialization to the public about the negative impact of internet pornography, this is a constraint of law number 44 of 2008 on pornography.

\subsection{Criminal Provisions Against Cyberporn Actors}

The criminal provisions in the law number 44 of 2008 related to Cyberporn crime, among others:

1. Article 29 reads Everyone who produces, reproduces, offers, sells, imports, exports, offers, sells, leases or provides pornography as referred to in Article 4 paragraph (1) shall be subject to imprisonment of a minimum of 6 (six) months and a maximum of 12 (twelve) years and / or a fine of at least Rp 250,000,000.00 (two hundred and fifty million rupiah) and a maximum of $\operatorname{Rp} 6,000,000,000.00$ (six billion rupiah).

2. Article 30 reads, Everyone providing pornographic services as referred to in Article 4 paragraph (2) shall be punished with imprisonment of at least 6 (six) months and a maximum of 6 (six) years and / or a fine of at least Rp 250,000. 000,00 (two hundred and fifty million rupiah) and a maximum of $\mathrm{Rp} 3,000,000,000.00$ (three billion rupiah).

3. Article 31 reads, Everyone who lends or downloads pornography as referred to in Article 5 shall be liable to a maximum imprisonment of 4 (four) years and / or a fine of not more than $\operatorname{Rp} 2,000,000,000.00$ (two billion rupiah).

Article 32 reads, Everyone who played, display, use, possess or store pornographic products as referred to in Article 6 shall be liable to a maximum imprisonment of 4 (four) years and / or a fine of not more than $\operatorname{Rp~2,000,000,000.00~(two~billion~rupiah).~}$

\footnotetext{
${ }^{14}$ Putra, E. N. (2015). Kejahatan Tanpa Korban Dalam Kejahatan Cyberporn. Jurnal Cakrawala Hukum, 6(1). p.141.
} 
Articles 29 through 32 mention every person, it is clear that anyone who accesses porn sites on the internet then the threat of punishment is clear. Pornographic acts on the internet have been mentioned in detail in those articles, so the legal certainty is clear that access to porn sites on the internet violates the law with clear sanctions.

There are two possible statuses when a person is involved in articles in the Pornography Act, which becomes:

1. Witness Status: may provide information for the purpose of investigation, prosecution and trial of a criminal case which he hears personally; or instantly become

2. Suspect Status: because of his actions or circumstances based on preliminary evidence is suspected to be a crime. Remember also that the status of a witness can be a suspect status. It should also be borne in mind that the maximum penalty sanction in this Law is a minimum imprisonment of 6 (six) months and no later than 12 (twelve) years and / or a fine of at least Rp 250,000,000.00 (two hundred and fifty tens of millions of rupiah) and at most $\operatorname{Rp~6,000,000,000.00~(six~billion~rupiah).~}$

Sanctions in the form of prison confinement and fines in the criminal provisions of pornography law is very heavy. This is to provide a deterrent effect to Internet users not to commit unlawful acts of accessing pornographic sites that conflict with pornography laws.

\section{Conclusion}

In this research, pornography can create access to other moral crimes such as rape, fornication, trafficking in women, trafficking in children, deviant sexual behavior and so on. Besides, pornography is prohibited by religious norms and morality norms in society, therefore the act is seen as a disgraceful and immoral act. Pornography can be linked as a form of crime which contains clear sanctions and is regulated in law. The role of pornography law is as a filter of a criminal act of pornography, especially internet pornography in order to occur restrictions for users of internet sites to not do things that smell porn on a virtual world site that is the internet.

This research it is clear that the criminal provisions in the law number 44 of 2008 on pornography is quite clear. Anyone who accesses pornographic sites on the internet is threatened with clear criminal sanctions. In juridical terms, criminal provisions in pornography law provide clear legal certainty and provide sanctions for internet users in accessing porn sites. Criminal provisions have been set forth in article 29 to article 32 of law number 44 of 2008 on pornography.

\section{Bibliography}

\section{$\underline{\text { Books }}$}

Hamzah, A., \&Marsita, B. D. (1987). Aspek-aspek pidana dibidang komputer. Jakarta: Sinar Grafika.

Hamzah, A. (2009).Delik-DelikTertentu (SpecialeDelicten) di dalam KUHP. Jakarta:SinarGrafika.

Makarim, E. (2003). Kompilasi hukum telematika. Jakarta: Raja GrafindoPersada. 
Manan, A. (2005). Aspek-aspek pengubah hukum. Jakarta: Kencana.

Qohar, A., \&Mas'udKharsan, D. K. K. (2004). Kamus Istilah Pengetahuan Populer. Gresik: CV Bintang Pelajar

Ranuhandoko. (2008).TerminologiHukumInggris-Indonesia. Jakarta: Sinar Grafika.

Sukanto, S., \&Mamudji, S. (2009). Penelitian Hukum Normatif Suatu Tinjauan Singkat, Cet. 11. Jakarta: PT. Raja GrafindoPersada.

Sudarto, (1986). Hukum dan Hukum Pidana. Bandung.Alumni.

\section{Journals}

Sudjito, B., Majid, A., Sulistio, F., \&Ruslijanto, P. A. (2016). Tindak Pidana Pornografidalam Era Siber di Indonesia.WACANA, JurnalSosial dan Humaniora, 19(2), 66-72. http://dx.doi.org/10.21776/ub.wacana.2016.019.02.1

Bunga, D. (2011). Penanggulangan Pornografi dalam Mewujudkan Manusia Pancasila. Jurnal Konstitusi, 8(4), 453-478.

Byrne, J., \& Burton, P. (2017). Children as Internet users: how can evidence better inform policy debate?. Journal of Cyber Policy, 2(1), 52.https:// doi.org/10.1080/23738871.2017.1291698

Demetrovics, Z., Szeredi, B., \&Rózsa, S. (2008). The three-factor model of Internet addiction: The development of the Problematic Internet Use Questionnaire. Behavior Research Methods, 40(2), 563-574. https:// doi.org/10.3758/BRM.40.2.563

Khakim, M. (2016). Undang-Undang Pornografi Dalam Tinjauan Politik Hukum Pidana. Jurnal Hukum Novelty, 7(3), 43-56.

Putra, E. N. (2015). KejahatanTanpa Korban DalamKejahatan Cyberporn. JurnalCakrawalaHukum, 6(1), 1-12.

Raharjo, A. (2007). Kajian YuridisTerhadap Cyberporn Dan UpayaPencegahan Serta Penanggulangan Penyebarannya di Internet. JurnalHukumRespublica, 7(1), 33-46

Saputra, D. E. (2017). Kajian Yuridis Terhadap Tindak Pidana Pornografi Melalui Media Sosial. Al Adl: Jurnal Hukum, 9(2), 263-286.

\section{Legal Documents}

Convention on Cybercrime, Budapest, 23.XI.200.

Criminal code (KitabUndang-UndangHukumPidana)

ETS 185-Convention on Cybercrime. Budapest. 23.XI.200.

Law Number 11 Year 2008 on ITE (Information and Electronic Transactions)

Law Number 44 Year 2008 on Pornography. 